\title{
Further Investigation into the Flavonoid Profile of Balsamorhiza Macrophylla (Nutt.) A. Gray
}

\section{(Asteraceae)}

\author{
Joseph C. Onyilagha (Corresponding author) \\ Department of Biology, University of Arkansas at Pine Bluff \\ 1200 North University Drive, Mail Slot 4972, Pine Bluff, AR 71601, USA \\ E-mail: onyilaghaj@uapb.edu
}

Francisca N. Nnajiofor

Department of Vocational Education, Faculty of Education

Nnamdi Azikiwe University, Awka, Nigeria

E-mail: nnajinebe@yahoo.com

Received: April 12, 2016 Accepted: May 4, 2016

doi:10.5296/jbls.v7i2.9572 URL: http://dx.doi.org/10.5296/jbls.v7i2.9572

\begin{abstract}
This research has identified the vacuolar flavonoids of Balsamorhiza macrophylla Nutt., which consist of Quercetin-3-O-galactoside, Quercetin-3-O-rutinoside, and Quercetin-7-O-glucoside. Exudate lipophilic flavonoids were also investigated. Results vary slightly from those of earlier study. This study shows the presence of Quercetin 3 - O methyl ether, Quercetin 3,6,4'- O - trimethyl ether, Quercetin 3,4'-O-dimethyl ether, 3,3'-O-dimethyl ether and an unknown compound which absorbs at 290nm, possibly a flavanone. The first three compounds agree with earlier results, which also include Tamarexetin, Axillarin and Spinacetin. Workers had reported earlier that flavonoid profiles often vary due to environmental or ecological differences, and whether this applies to Balsamorhiza macrophylla is part of this investigation.
\end{abstract}

Keywords: Balsamorhiza macrophylla, Asteraceae, flavonoid, quercetin O-glycosides, quercetin O-methyl ether 


\section{Introduction}

Flavonoids are phenolic compounds with nuclei arranged in a $\mathrm{C}_{6}-\mathrm{C}_{3}-\mathrm{C}_{6}$ configuration (see Figure 1). They are one of the largest groups of naturally occurring phenolic compounds, which are likely to be encountered in any plant extract (Markham, 1982). Most flavonoids are glycosylated, and glycosylation makes them less reactive and more water (sap) soluble (Onyilagha, 1994; Onyilagha and Grotewold, 2004). This in turn helps in the storage of these compounds in the cell vacuole, where they are often found (Grotewold, 2004). Plant flavonoids are generally stored in the vacuoles (Harborne and Turner, 1984). However, some flavonoids are known to accumulate on the surfaces of leaves, flowers, and other tissues. These are known as surface, external, or exudate flavonoids. In some cases, they are simply referred to as lipophilic flavonoids (Williams et al., 1993). It should be noted however, that some vacuolar flavonoids are also lipophilic in nature. For example, the plant species Vellozia streptophylla (Velloziaceae) accumulates lipophilic flavonoids such as quercetin 3-methyl ether, and quercetin 3,4'-dimethyl ether in their leaf vacuoles (Williams et al., 1993), but these compounds appear as leaf surface flavonoids in Balsamorhiza macrophylla (Asteraceae) (McCormick et al., 1985). Research results are overall consistent in showing that surface flavonoids are predominantly aglycones, although the presence of quercetin 7-O-glucoside was reported in leaf exudates of Chrysanthemum segetum, and quercetin 3-O-glucoside, quercetagetin $O$-3-glucoside and quercetagetin 6-Me-7-O-glucoside in leaf exudates of Heteranthemis viscidehirta (Valant-Vetschera et al., 2003).

The plant species, Balsamorhiza macrophylla (Nutt.) A. Gray is one of the shrubby members of the family Asteraceae (Heliantheae - Verbesininae). Bremer (1994) has given a detailed account of the family and placed the genus under the subtribe Verbesininae, members of which are widely distributed in North and South America, Africa, tropical Asia and the Pacific. The genus Balsamorhiza is however resitricted to western United States, southwestern Canada and Mexico (Bremer, 1994). Keil (1993) described Balsamorhiza macrophylla as a shrub with erect stems and branching from base. Leaves are short petioled, ovate to round, entire to serrate-lobed, glandular. Inflorescence characteristically a head, 10 12mm, 1 - 3 per panicle on short branches.

Earlier studies (McCormick et al., 1985; Bohm and Choy, 1987) show that members of the genus Basalmorhiza are rich in both exudate and vacuolar flavonoids. Although the exudate flavonoids of Balsamorhiza macrophylla had been studied, the vacuolar flavonoid profile is not yet given equal attention. This study is designed to identify the vacoular flavonoids of Balsamorhiza macrophylla and to determine whether flavonoids in this species vary due to environmental or ecological differences. 
<smiles>O=c1c(O)c(-c2ccc(O)c(O)c2)oc2cc(O)cc(O)c12</smiles>

quercetin<smiles>O=c1c(O)c(-c2ccc(O)c(O)c2)oc2cc(O)c(O)c(O)c12</smiles><smiles>O=c1c(O)c(-c2ccccc2)oc2ccccc12</smiles>

\section{quercetagetin}

Figure 1. Basic structure of quercetin, quercetagetin and flavonol flavonoids. Quercetin is a flavonol with $\mathrm{OH}$ (hydroxy) group at 3, 5, 7, 3', 4' positions. Kaempferol is a flavonol with $\mathrm{OH}$ group at 3, 5, 7, 4' positions. Quercetagetin is a flavonol with $\mathrm{OH}$ group at 3, 5, 6, 7, 3', 4' positions

\section{Materials and Methods}

Plant material: Leaves of Balsamorhiza macrophylla were collected on the hills east of Hyde Park, about 50 kilometers south of Cache National Forest, Utah, in the United States. A voucher specimen is deposited in our laboratory.

Extraction and separation of surface flavonoids: Flavonoid extractions followed the procedures as detailed in Onyilagha and Grotewold (2004); McCormick et al. (1985). Briefly, dried leaves were washed three times in methylene dichloride to extract the surface flavonoids. The extract was taken to dryness in-vacuo. The residue was extracted with $\mathrm{MeOH}$ and chromatographed over a polyclar AT column using dichloro-methane : methanol $(3: 1)$ and with increasing amounts of $\mathrm{MeOH}$. Fractions from the column were further separated on silica gel $\mathrm{G}$ plate using toluene-acetic acid (4:1). Flavonoid bands were separately chromatographed in $30 \%$ HOAc on cellulose avicel plates and finally resolved on polyamide layer using ethyl formate, cyclohexane, n-butanol, formic acid (50:25:23:2 respectively).

Vacuolar flavonoids: The washed leaf materials were completely air dried prior to determination of the vacuolar flavonoids. About $50 \mathrm{~g}$ dried leaves were extracted in $70 \%$ ethanol in a boiling water-bath for $10 \mathrm{~min}$ (Onyilagha, et al., 2009). The extract was allowed to stand overnight for complete extraction, and then evaporated to dryness using a rotary evaporator. The residue was extracted with boiling water, filtered, and the flavonoids then extracted in saturated n-butanol. The butanol extract was dried in-vacuo and the flavonoids taken up in $\mathrm{MeOH}$. Subsequent treatments followed the methods of Onyilagha et al. (2003).

Flavonoid aglycones: About $5 \mathrm{~g}$ of macerated dry leaves were hydrolyzed in approximately $20 \mathrm{ml}$ of $2 \mathrm{M} \mathrm{HCl}$ in a glass tube, followed by heating in a boiling water-bath for $10 \mathrm{~min}$, and cooled at room temperature. Flavonoid aglycones were extracted in ethyl-acetate, and the ethyl acetate was evaporated in fume-hood. Subsequent treatments of flavonoid residues followed the same process as shown in Poe et al. (2013).

The exudate, vacuolar, and aglycone flavonoids are known compounds. They were readily identified by their colour under the UV light in the presence of ammonia fumes, and by 
comparing their rf values, retention time in hplc, and spectral data with information from literature (Onyilagha, 1994; Williams, et al., 1993, 1995; McComick, et al., 1985). They were also subjected to co-chromatography with authentic markers in three solvents such as BAW, FORESTAL, and 50\% acetic acid in water (Harborne and Harborne, 1998; Onyilagha, 1994).

\section{Results}

Three vacuolar and five exudate compounds were identified. Quercetin was the only aglycone flavonoid identified from acid hydrolysed plant leaf materials. The vacuolar flavonoids were quercetin 3-O-galactoside, quercetin 3-O-rutinoside (rutin) and quercetin 7-O-glucoside. The exudate flavanoids were quercetin 3-O-methyl ether; quercetin 3,3'-O-dimethyl ether; quercetin 3,4'-O-dimethyl ether; quercetagetin 3,6,4'-O-trimethyl ether and one unknown compound (Table 1). The unknown compound has a single peak, which absorbs at 290nm, possibly a derivative of flavanone.

Table 1. Vacuolar and exudate flavonoids in Balsamorhiza macrophylla

\begin{tabular}{|c|c|c|c|}
\hline \multirow[b]{2}{*}{ Flavonoid Group } & \multicolumn{2}{|c|}{ Plant Leaf Materials Were Obtained From: } & \multirow[b]{2}{*}{ Reference } \\
\hline & Hyde Park, Utah, USA & Tony Grove, Utah, USA & \\
\hline \multicolumn{4}{|l|}{ Vacuolar Flavonoids: } \\
\hline Qu 3-galactoside & $\checkmark$ & & In this study \\
\hline Qu 3-rutinoside & $\checkmark$ & & In this study \\
\hline Qu 7-glucoside & $\checkmark$ & & In this study \\
\hline \multicolumn{4}{|l|}{ Exude Flavonoids: } \\
\hline Qu 3-methyl ether & $\checkmark$ & $\checkmark$ & $\begin{array}{l}\text { In this study \& } \\
\text { McCormick et } \\
\text { al., } 1985\end{array}$ \\
\hline Qu 3,3'-dimethyl ether & $\checkmark$ & & In this study \\
\hline Qu 3,4'-dimethyl ether & $\checkmark$ & $\checkmark$ & $\begin{array}{ll}\text { In this study } \& \\
\text { McCormick et } \\
\text { al., } 1985\end{array}$ \\
\hline $\begin{array}{l}\text { Quercetagetin 3,6,4'-trimethyl ether } \\
\text { (Centaureidin) }\end{array}$ & $\checkmark$ & $\checkmark$ & $\begin{array}{l}\text { In this study \& } \\
\text { McCormick et } \\
\text { al., } 1985\end{array}$ \\
\hline Unknown (Flavanone?) & $\checkmark$ & & In this study \\
\hline $\begin{array}{l}\text { Quercetagetin 3,6-dimethyl ether } \\
\text { (Axillarin) }\end{array}$ & & $\checkmark$ & $\begin{array}{l}\text { McCormick et } \\
\text { al., } 1985\end{array}$ \\
\hline $\begin{array}{l}\text { Quercetagetin 3',6-dimethyl ether } \\
\text { (Spinacetin) }\end{array}$ & & $\checkmark$ & $\begin{array}{l}\text { McCormick et } \\
\text { al., } 1985\end{array}$ \\
\hline Qu 4'-methyl ether (Tamarexetin) & & $\checkmark$ & $\begin{array}{l}\text { McCormick et } \\
\text { al., } 1985\end{array}$ \\
\hline
\end{tabular}

$\mathrm{Qu}=$ Quercetin

A comparison of our results with earlier study (McCormick et al., 1985) is shown in Table1. The absence of surface flavonoids such as axillarin, spinacetin and tamarexetin in our 
specimen is very noticeable and same may be said of the absence of vacuolar flavonoids and surface compounds, example, quercetin 3,3'-O-dimethyl ether and flavanone-like (derivative) compound from the specimens of the earlier workers.

\section{Discussion}

Results point to the dominance in this species of quercetin based flavonoids in both the vacuolar and exudate compounds. This agrees with the results of McCormick et al., (1985). The inability of this species to accumulate kaempferol to a detectable concentration seems to be an important characteristic. However, there is need to study the flavonoid profiles in other species of Balsamorhiza to enable an informed statement on the use of quercetin flavonoid as a taxonomic marker in this genus. Accumulation of exudate lipophilic flavonoids in the species is not surprising because the species is a member of the plant family Asteraceae, a family whose species have been known to accumulate varying structures of flavonoids on their leaf surfaces (Onyilagha and Grotewold, 2004).

The lack of agreement in results of accumulated surface flavonoids in this study and that of McCormick et al (1985) is surprising. This study did not detect axillarin, spinacetin and tamarexetin flavonoids as did McCormick and co-workers, and they did not detect quercetin 3,3'-O-dimethyl ether and a flavanone derivative as we did. In a similar situation, Rieseberg et al (1987) observed considerable variation in flavonoid profile in Helianthus annuus, but could not show a definable phytogeographic patterns among the compounds detected. Nevertheless, plant materials used by McCormick and co-workers were obtained from Tony Grove, Cache National Forest, Cache Co, Utah, USA. Our specimen was obtained from hills east of Hyde Park, about 50km South of Cache National Forest, Utah. Although environmental or ecological situations influence flavonoid accumulation, but it may be too hasty to suggest that environmental and/or ecological differences between the two sites may have contributed to the variation in flavonoid compounds accumulated because many more species of this genus need to be investigated. However, Bohm (1987) in studying the flavonoids of Luetkea species from different populations in North America observed that the southernmost populations showed increased tendency to produce acylated flavonoid monoglucosides, coupled with decreased levels of eriodictyol 7-O-glucoside. Samples from the Queen Charlotte Islands were different apparently due to the absence of eriodictyol 7-O-glucoside. In another study, Wells and Bohm (1988) observed some variations in flavonoid compounds of Luetkea pectinata materials from different locations. In relation to the present study, it may not be adequate at this moment to regard the species, Balsamorhiza macrophylla or indeed the genus Balsamorhiza as a group that exhibits inter-populational flavonoid variation. It may be necessary therefore to study many more specimens from several other locations in order to arrive at a convincing conclusion.

\section{Acknowledgement}

The contributions of late Professor J. B. Harborne and late Professor Neil Towers (PhD supervisor and post-doc mentor respectively for first author) to our understanding of the biology of plant flavonoids are greatly appreciated and acknowledged. 


\section{References}

Bohm, B. A., (1987). Intraspecific flavonoid variation. The Botanical Review, 53(2), 197-279. http://dx.doi.org/10.1007/BF02858524.

Bohm, B. A., \& Choy, J. B., (1987). Flavonoids of Balsamorhiza deltoidea and Wyethiamollis. Biochemical systematics and ecology, 15(5), 541-543. http://dx.doi.org/10.1016/0305-1978(87)90102-5.

Bremer, K., (1994). Asteraceae. Timber press, Portland, 752pp.

Grotewold, E., (2004). The challenges of moving chemicals within and out of cells: insights into the transport of plant natural products. Planta, 219(5), 906-909. http://dx.doi.org/10.1007/s00425-004-1336-0

Harborne, J. B., \& Harborne, A. J., (1998). Phytochemical Methods a Guide to Modern Techniques of Plant Analysis. Kluwer Academic Publishers, London, U.K.

Harborne, J. B., \& Turner, B. L., (1984). Plant Chemosystematics, Academic Press, London.

Keil, D. J., (1993). Asteraceae. In " The Jepson Manual. Higher plants of California". Hickman,

J. C. (ed.). University of California press, Berkley, pp 174 - 364.

Markham, K. R., (1982). Techniques of flavonoid identification, Academic Press, London. McCormick, S., Robson, K., and Bohm, B. A., (1985). Methylated flavonols from Wyethia bolanderi and Balsamorhiza macrophylla. Phytochemistry, 24(9), 2133. http://dx.doi.org/10.1016/S0031-9422(00)83143-X

Onyilagha, J. C. (1994). Phytochemical studies of the genus Phaseolus and some related genera, with special reference to their flavonoid patterns. PhD Thesis, University of Reading, England.

Onyilagha, J. C., Bala, A., Hallett, R., Gruber, M., Soroka, J., \& Westcott, N., (2003). Leaf flavonoids of the cruciferous species, Camelina sativa. Crambe spp., Thlaspi arvense and several other genera of the family Brassicaceae. Biochem. Syst. Ecol. 31, 1309-1322. http://dx.doi.org/10.1016/S0305-1978(03)00074-7

Onyilagha, J. C., \& Grotewold, E. (2004). The biology and structural distribution of surface flavonoids. Recent research developments in plant science. 2, 53-71. http://www.cabdirect.org/search.html

Onyilagha, J. C., Islam, S., \& Ntamatungiro, S. (2009). Comparative phytochemistry of eleven species of Vigna (Fabaceae). Biochemical Systematics and Ecology, 37(1), 16-19. http://dx.doi.org/10.1016/j.bse.2008.11.013

Poe, M. L., Bates, A., \& Onyilagha, J. (2013). Distribution of Leaf Flavonoid Aglycones and Glucuronides in the Genus Phaseolus and Related Genera. International Journal of Biology, 5(4), 36. http://search.proquest.com/docview/1468459084?accountid=28881

Rieseberg, L. H., Soltis, D. E., \& Arnold, D., (1987). Variation and localization of Flavonoid 


\section{Macrothink}

aglycones in Helianthus annuus (Compositae). American Journal of Botany, 224-233. http://www.jstor.org/stable/2444024

Valant-Vetschera, K. M., Wollenweber, E., Faure, R., \& Gaydou, E., (2003). New exudate flavonoids of species from the Chrysanthemum complex (Asteraceae-Anthemideae). $\begin{array}{llll}\text { Biochemical systematics and ecology, 31(5), 545-548. } & \text { and }\end{array}$ http://dx.doi:10.1016/S0305-1978(02)00184-9.

Wells, T. C., \& Bohm, B. A. (1988). Flavonoids of Luetkea pectinata (Rosaceae: Spiraeoideae). Biochemical systematics and ecology, 16(5), 479-483. http://dx.doi.org/10.1016/0305-1978(88)90048-8

Williams, C. A., Onyilagha, J. C., \& Harborne, J. B. (1995). Flavonoid profiles in leaves, flowers and stems of forty-nine members of the Phaseolinae. Biochemical systematics and ecology, 23(6), 655-667. http://dx.doi.org/10.1016/0305-1978(95)00040-2

Williams, C. A., Harborne, J. B., Greenham, J., Eagles, J., \& Markham, K. R., (1993). Six further lipophilic flavonols from the leaf of Vellozia stipitata. Phytochemistry, 32(3), 731-735. http://dx.doi.org/10.1016/S0031-9422(00)95162-8.

\section{Copyright Disclaimer}

Copyright for this article is retained by the author(s), with first publication rights granted to the journal.

This is an open-access article distributed under the terms and conditions of the Creative Commons Attribution license (http://creativecommons.org/licenses/by/3.0/). 